\title{
LYSOZYME LEVEL DURING ACUTE INFECTION OF BACTERIUM Aeromonas salmonicida SUBSP Salmonicida IN HALIBUT AND ATLANTIC SALMON
}

Institute of Aquaculture, University of Stirling, Scotland, UK

\section{Devadason $\mathrm{C}^{*}$}

Received - November 28, 2017; Revision - January 19, 2018; Accepted - February 11, 2018

Available Online - February 20, 2018

DOI: http://dx.doi.org/10.18006/2018.6(1).236.242

\section{KEYWORDS \\ Turbidometric \\ Humoral \\ Bactericidal \\ Serum killing}

\begin{abstract}
Lysozme, a humoral defence protein, played an important bactericidal activity in Atlantic salmon and halibut. Turbidometric and bactericidal killing assays were used to determine the lysozyme level and serum killing activity respectively. A challenged experiment in native halibut (Hippoglossus hippoglossus) with different doses $\left(10^{3}, 10^{5}, 10^{9}\right)$ of Aeromonas salmonidae (MT423) has been proved that there is no significant relationship between the lysozyme level and bactericidal killing activity (p>0.005). Lysozyme level in halibut serum was significantly higher than that of Atlantic salmon serum. Lysozyme activity of serum collected from fish during the summer was found to be significantly higher, ranging from 650 to $850 \mu \mathrm{g}$. Halibut serum showed varying level of killing activity (KI) during summer (0.266-0.873) and winter (0.255-1.344) whereas Atlantic salmon had very poor killing activity (0.414 -6.867). There was no correlation between the lysozyme activity of the serum and bactericidal activity in the serum of $A$. salmonicida infected halibut.
\end{abstract}

* Corresponding author

Department of Zoology, Eastern University, Sri Lanka Chenkalady

E-mail: chand_oo@yahoo.com (Chandravathany Devadason)

Peer review under responsibility of Journal of Experimental Biology and Agricultural Sciences.

Production and Hosting by Horizon Publisher India [HPI] (http://www.horizonpublisherindia.in/).

All rights reserved.
All the article published by Journal of Experimental Biology and Agricultural Sciences is licensed under a Creative Commons Attribution-NonCommercial 4.0 International License Based on a work at www.jebas.org.

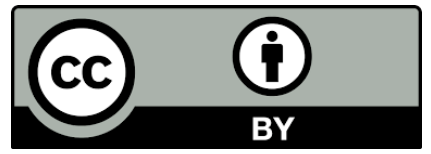




\section{Introduction}

Fin fish and shell fish farming have been commercialized to fulfill the protein requirement of rapidly arising population and is one of the fastest growing food production sectors in the world, but infections caused by bacteria, viruses, and parasites cost the industry billions of dollars in worldwide losses each year (Ugelvik et al. 2017). Salmon louse infection and economic losses reported by Costello, (2009). Lysozyme is considered to play an important role in humoral defence mechanisms in fish (Lindsay, 1986). These lysozyme are associated with innate immunity, which forms the first line of defense against infections, however, its primary role is lysis of the bacterial cell wall and opsonization (Alhazmi et al., 2014). Lysozyme (mucopeptide-N-acetyl muramylhydrolase) is a low molecular weight cationic protein which hydrolyses N-acetylmuramic-b-1-4-acetyly glucosamine linkages in bacterial cell wall (Ossermann \& Lawlor, 1966) particularly sugars moiety of the peptidoglycan of the cell wall of gram (+) ve bacteria causing lysis and seems likely that lysozyme may also play a role in the destruction of some gram (-)ve bacteria (Grinde, 1989). These lysozyme has been detected in blood, mucus and phagocytic cells of fish (Fletcher \&White,1973; Studnicka et al., 1986). Further, its presence in the blood of invertebrates was also reported by Barnes (1974). Cheng et al. (1977) used the tubidometric assay to determine the lysoszyme activity in the hemolymph of Biophalaria glabrate challenged with heat killed Bacillus megaterium. Similarly, Fletcher \&White (1973) and Murray \& Fletcher (1976) found that lysozyme was consistently present throughout the year in the sera of flat fish, including plaice (Pleuronectes plattessa L.), flounder (Platichthys flesus L) and turbot (Scophthalmus maximus L). Lysozyme levels have been increase to response of microbial attack and physical stress (Ingram, 1980). Mock \&Peters (1990) reported reduction in lysozyme concentration in response to stress in rainbow trout. Reddy et al. (2004) and Wang et al. (2005) are employed to the study of lysozyme activity and serum bacterial killing activity (Ourth \&Wilson, 1981) and macrophage killing activity (Sharp \& Secombes, 1993). Lysozyme isolated from rainbow trout (Oncorhynchus mykiss) serum also have bacteriacidal activity against a range of Gram (-)ve bacterial pathogens of fish, including Vibrio salmonicida, Aeromonas salmonicda and Yersinia ruckeri (Grinde, 1989; Rainger \& Rowley AF, 1993). A. salmonicida, the etiological agent of furnculosis in trout and salmon, has been a worldwide economic threat to intensive culture of the commercial valuable fish for over fifty years (McCarthy \& Roberts, 1980). A. salmonida subsps salmonicida is gram (-)ve bacteria , non-motile, fermentative rods which produce cytochrome oxidase and catalase. It can be differentiated on the basis of their biochemical properties and the ability to produce a brown water-soluble pigment when culture on media containing tyrosine (Austin \& Austin, 1987). This study was designed to understand the antibacterial properties of lysozyme against Aeromonas salmonicida gram (-)ve virulent bacteria.

\section{Materials and Methods}

\subsection{Collection of Serum and Mucus from healthy fish}

The healthy halibut $(n=11)$ and Atlantic salmon $(n=11)$ were obtained from the Scottish office of Agriculture Environment and fisheries department (SOAEFD) field station, Scotland and were lightly anaesthetized by immersion in benzocaine (ethyl-paminobenzoate). Samples of mucus were scraped from the dorsal surface using a scalpel and store at $-20^{\circ} \mathrm{C}$ until use. Blood samples were taken from the caudal vein using a $23 \mathrm{G}$ needle and syringe and allowed to clot at room temperature (RT). The blood samples were then centrifuged at $4000 \mathrm{~g}$ for $15 \mathrm{~min}$, the serum collected and stored at $-20^{\circ} \mathrm{C}$ until required for assay.

\subsection{Infectivity trial}

Two year old halibut, weight range from $250 \mathrm{~g}-300 \mathrm{~g}$ were reared in seawater in $1 \mathrm{~m}$ diameter plastic tanks. They were fed daily on commercial dry pellets and appeared to be healthy with no signs of disease. The effect of intraperitonial injection of three doses of A. salmonicida viz., $10^{9}, 10^{5}, 10^{3}$ cells/fish was examined. There were four fish per test and control group fish which were injected with sterile phosphate buffer solution (PBS). Each group of fish was maintained in seawater in separate $0.75 \mathrm{~m}$ diameter circular tanks with continuous aeration. To reduce the risk of cross contamination, the tanks were covered with polythene sheeting. The temperature of the seawater was monitored throughout the experiment. Prior to the infection of bacteria, the fish in each group were lightly anaesthetized as described above, and a $1 \mathrm{ml}$ sample of blood was taken from the caudal vein using $23 \mathrm{G}$ needle and syringe, to enable measurement of pre-infection levels of lysozyme. Each fish was then individually dye-marked using a pan-jet loaded with alcian blue, and injected intraperitonially with 100microlitre of the appropriate dose of A. salmonicida for test fish, or sterile PBS for control fish. Blood samples were taken as described above, after 4 and $8 \mathrm{hrs}$. After 24hrs the fish were killed and bled using a vacutainer and needle (Greiner). The blood samples were allowed to clot at RT, and were then centrifuged at $3000 \mathrm{~g}$ for $10 \mathrm{~min}$ to collect the serum. Samples were stored at $4{ }^{0} \mathrm{C}$ during the trial, and on return to the laboratory, were stored at $20^{\circ} \mathrm{C}$ until required for assay. The serum samples from individual fish in each group were assayed for lysozyme activity and bactericidal activity using the turbidometric assay and serum bactericidal assay Pech (1985).

\subsection{Turbidometric Assay}

This assay was a modification of the method of Parry et al. (1965), which is based on a decrease in optical density (OD) or 
absorbance due to the lysis of bacterial cells by lysozyme. Before this assay was applied, it was optimized. Micorcoccus lysodeikticus $(80 \mathrm{mg} / \mathrm{ml}$ in $0.05 \mathrm{M}$ sodium phosphate buffer, $\mathrm{pH}$ 6.2) was added to varying concentration of hen egg white lysozyme as four replicates in a microtitre plate. Sterile PBS added Micorcoccus lysodeikticus was used as a negative control and sterile PBBS alone as a blank. The decrease in OD per minute, measured at $540 \mathrm{~nm}$ and $370 \mathrm{C}$ was recorded using a Dynatech MR 7000 microplate reader. Lysozyme was measured in terms of units, where one unit is equivalent to a decrease in OD of 0.001 per minute $(\mathrm{DOD} / \mathrm{min}=0.001)$. Lysozyme activity of serum and mucus was determined using this assay. Sterile twofold dilutions of each serum and mucus samples, range from 1:5 to 1:5120, at 100microlitre per well were set up. The Micorcoccus lysodeikticus at a concentration of $0.4 \mathrm{mg} / \mathrm{ml}$ was dispersed by a Dynatech MR 7000 reagent dispenser at 100microliter per well. The plate was shaken for $20 \mathrm{sec}$ and the OD read at $1 \mathrm{~min}$ intervals at $540 \mathrm{~nm}$ and RT over a 5 min period.

\subsection{Culture of Aeromonas salmonicida (MT 423)}

A. samonicida (MT423), which is highly virulent, A layer possessing form, was obtained from the SOAEFD, Aberdeen, and cultured on tryptone soya broth (TSB, Oxoid) was seeded from the agar culture, and incubated at $22^{\circ} \mathrm{C}$ for $16 \mathrm{~h}$ to reach $\log$ phase growth. The bacterial cells were pelleted by centrifugation at $2000 \mathrm{~g}$ for $10 \mathrm{~min}$ at $22^{\circ} \mathrm{C}$, and washed twice in sterile PBS. The cells were then resuspended in sterile PBS and aggregated bacteria were dispensed by passage through a $26 \mathrm{G}$ needle. The bacterial suspension was measured spectrophotometrically and adjusted to give a density of $10^{9}$ cells $/ \mathrm{ml}$ in PBS (OD=1.0at $540 \mathrm{~nm})$.

\subsection{Serum Bactericidal Assay}

This assay utilizes the reduction of the tetrazolium dye MTT by bacterial dehydrogenases as an indicator of bacterial viability. This reduction is directly proportional to the number of viable bacteria present. Measurement of a decrease in MTT reduction after incubation with serum is an indication of serum killing. Each serum sample to be tested diluted as 1:10 in sterile PBS and heat inactivated samples of each sera $\left(50^{\circ} \mathrm{C}\right.$ for $\left.1 \mathrm{hr}\right)$ in duplicates at a volume of 50 microliter were added respective wells in the microtitre plate. Once serum samples were loaded, the microtitre plate was exposed to $\mathrm{UV}$ radiation for $1 \mathrm{hr}$ to sterilize the serum and reduce the risk of bacterial contamination. Following this, 100 microliter of the bacterial suspension was added to each test well using the Dynatech MR7000 reagent dispenser and the plate was shaken for 20s. A 100 microliter replicates of 1:10 serum diluted with PBS and 100microliter replicates of bacteria suspension were used as controls. A 150microlitre replicates of sterile PBS was used as blank. For each assay, two identical plates were prepared, plate A $0 \mathrm{hr}$ and plate B for $1 \mathrm{hr}$ were incubated at $18^{\circ} \mathrm{C}$. After the set incubation time, the microtitre plate was read at $630 \mathrm{~nm}$ on a Dynatech MR 7000 microtitre plate reader to measure the background absorbance. Immediately, 10microlitre of MTT $(5 \mathrm{mg} / \mathrm{ml}$ in $\mathrm{dH} 2 \mathrm{O}$ ) was added to each well, the plate was shaken, and after exactly $15 \mathrm{~min}$, OD was recorded. The reduction in OD after $1 \mathrm{hr}$ is an indication of the killing potential of the serum (Pech, 1985).

The killing index (KI) of each serum was calculated from the equation

$$
K I=\frac{\text { MTT reduction after } 1 \mathrm{~h}}{\text { MTT reduction after } 0 \mathrm{hr}}
$$

Where $\mathrm{KI}$ is less than1.0, the serum show the killing activity

\subsection{Statistical Analysis}

Means and standard errors of the means were calculated for each data set and compared using the Student's t test. A one-way analysis of variance was used to analyze the data for degree differences between population data for lysozyme activity. Significance was measured at a $\mathrm{P}<0.05$ level.

\section{Results}

The lysozyme and bactericidal activities of the serum of Atlantic salmon and halibut showed no significant correlation between both fish $(\mathrm{P}>0.01)$. The lysozyme activity of serum of nonimmunized salmon showed variation in serum lysozyme activity between the individuals measured. Of the fish examined (n-11), seven showed low lysozyme activity from $80 \mu \mathrm{g}$ to $128 \mu \mathrm{g}$ whereas halibut serum collected from the fish during winter showed between $84-276 \mu \mathrm{g}$. In comparison, the lysozyme activity of serum collected from fish during the summer was found to be significantly higher in all samples measured $(n=11)$, ranging from 650 to $850 \mu \mathrm{g}$ ( Table 1 )

Of the salmon serum tested, only four serum samples showed bactericidal activity $(\mathrm{KI}<1.0)$, ranging from 0.90 to 0.40 , and the excessively high index may have been due to experimental variation of error within the assay. Halibut serum collected in winter showed bactericidal activity, with killing index of around 0.60 to 0.25 and three samples did not exhibit serum killing. In comparison, serum collected in summer showed bactericidal activity of varying levels, with killing index of from 0.09 to 0.25 (Table 2). At pre-injection level, all fish showed high levels of lysozyme activity of around $750 \mu \mathrm{g}$, the control fish showed remained constant $4 \mathrm{hr}$ after injection with sterile PBS and decreased significantly after $2 \mathrm{~h}$ around $350 \mu \mathrm{g}$ (Table3). The lysozyme activity of serum of the fish infected at a dose of $10^{3}$ cells/fish showed significant increases in lysozyme activity, after 
$24 \mathrm{hr}$ to a level of around $1300 \mu \mathrm{g}$. In the fish infected at a dose of $10^{5}$ cells /fish, the mean lysozyme activity levels indicated that there was no significant difference throughout the $24 \mathrm{hr}$ of period of trial. In the lysozyme activity at a dose of $10^{9}$ cells /fish, have some variation between individuals measured. The overall results showed no significant difference in mean lysozyme activity over $24 \mathrm{hr}$ period of the trial (Table3).

At pre-infection with sterile PBS, bactericidal activity of serum of control fish was shown with a killing index of around 0.060 . The serum of the fish infected at a dose of $10^{3}$ cells/fish showed preinfection bactericidal activity of varying levels, from killing index of 0.90 to 0.30 . Following infection, there was variation in killing potential between the individual fish measured, however, $8 \mathrm{hr}$ following infection, all the fish showed bactericidal activity of varying levels from a killing index of 0.85 to 0.25 . All the fish infected at a dose of $10^{5}$ cells/fish showed bactericidal activity with a killing index from 0.70 to 0.30 , however, after a $24 \mathrm{~h}$ period none of the fish showed significant bactericidal activity. The mean bactericidal activity shows a general upward trend in the killing index over $24 \mathrm{hr}$, indicating a loss of serum killing potential by the fish. The fish infected at a dose of $10^{9}$ cells/fish showed a similar pattern to those infected at $10^{5} \mathrm{cells} / \mathrm{fish}$. However, the mean levels showed a general reduction in serum killing ability over a $24 \mathrm{hr}$ period (Table 4). There was no observed correlation between the lysozyme activity of the serum and bactericidal activity in the serum of A. salmonicida infected halibut.

\section{Discussion}

This study was designed to understand the antibacterial properties of lysozyme against Aeromonas salmonicida gram (-)ve virulent bacteria. As lysozyme can be stress related factor, handling, transporting, anasthetising and withdrawal of blood can induce changes in levels of lysozyme. In control fish lysozyme activity decreases possibly due to stress. Mock \&Peters (1990) have shown that atypical response to stress in rainbow trout is a reduction in lysozyme concentration, as it was observed in control halibut. However, when bacteria were injected into the peritonial cavity of halibut, the complement cascade is activated by the antigens and lysozyme activity in serum increases. The variation in lysozyme levels in challenged fish may be due to the function of the non-specific humoral responses. The serum bactericidal activity shows no correlation with lysozyme activity in this study. High level of killing activity may be due to the activation of complement proteins due to alternative pathway. Lysozyme activity also gradually decreases throughout the experimental period suggesting that the lysozyme was being metabolized during the infection. It has been noted that $10^{9}$ cells/fish of Aeromonas salmonicida is a lethal dose for halibut (Bricknell et al. 2006) and there was no mortality over the $24 \mathrm{hr}$ period in halibut. At $10^{9}$ cells/fish injected, possibly due to bacterial toxins suppressing the
Table 1 Lysozyme level $(\mu \mathrm{g})$ and the serum bactericidal activity (KI) in halibut \pm serum collected during winter and summer.

\begin{tabular}{ccccc|} 
Number & $\begin{array}{c}\text { Lysozyme } \\
(\mu \mathrm{g})\end{array}$ & $\begin{array}{c}\text { KIndex } \\
(\mathrm{KI})\end{array}$ & $\begin{array}{c}\text { Sysozyme } \\
(\mu \mathrm{g})\end{array}$ & $\begin{array}{c}\text { K. Index } \\
(\mathrm{KI})\end{array}$ \\
\hline 1 & $91 \pm 05$ & 0.507 & $748 \pm 07$ & 0.722 \\
\hline 2 & $276 \pm 04$ & $1.344^{* *}$ & $732 \pm 03$ & 0.658 \\
\hline 3 & $276 \pm .02$ & 0.552 & $756 \pm 05$ & 0.357 \\
\hline 4 & $268 \pm 00$ & $1.166^{* *}$ & $648 \pm 02$ & 0.573 \\
\hline 5 & $126 \pm 10$ & 0.403 & $728 \pm 04$ & 0.873 \\
\hline 6 & $119 \pm 11$ & 0.336 & $640 \pm 06$ & 0.266 \\
\hline 7 & $244 \pm 01$ & 0.627 & $756 \pm 12$ & 0.426 \\
\hline 8 & $84 \pm 04$ & $1.152^{* *}$ & $736 \pm 15$ & 0.717 \\
\hline 9 & $142 \pm 06$ & 0.365 & $704 \pm 13$ & 0.293 \\
\hline 10 & $119 \pm 07$ & 0.357 & $732 \pm 19$ & 0.329 \\
\hline 11 & $144 \pm 12$ & 0.255 & $652 \pm 22$ & 0.656 \\
\hline
\end{tabular}

Value presented mean $\pm \mathrm{SD}$, ** indicates the non-killing activity of serum, $\mathrm{K}<1$-Killing activity of serum

Table 2 Lysozyme level (Microgram) and serum bactericidal activity (KI) of naïve Atlantic salmon serum

\begin{tabular}{|ccc|}
\hline Fish & Lyoszyme level $(\mu \mathrm{g})$ & Killing Index $(\mathrm{KI})$ \\
\hline 1 & $13 \pm 08$ & 0.414 \\
\hline 2 & $19 \pm 12$ & $1.727^{* *}$ \\
\hline 3 & $15 \pm 03$ & 0.723 \\
\hline 4 & $12 \pm 04$ & $1.000^{* *}$ \\
\hline 5 & $12 \pm 08$ & $1.689^{* *}$ \\
\hline 6 & $120 \pm 23 \#$ & $1.553^{* *}$ \\
\hline 7 & $112 \pm 16 \#$ & $4.442^{* *}$ \\
\hline 8 & $17 \pm 07$ & $6.867^{* *}$ \\
\hline 9 & $23 \pm 12$ & $1.131^{* *}$ \\
\hline 10 & $80 \pm 24$ & $1.420^{* *}$ \\
\hline 11 & $128 \pm 27 \#$ & $1.325^{* *}$ \\
\hline
\end{tabular}

\# indicates that only three fish show high level of lysozyme and the sign (**) indicates that 9 fish of total 11 fish show the non-killing activity

Table 3 The changes of lysozyme level (microgram) during the different doses of Aeromonas salmonicida (MT432) challenged experiment in naïve halibut

\begin{tabular}{|lcccc|}
\hline $\begin{array}{c}\text { Number of bacteria } \\
\text { challenged }\end{array}$ & $\begin{array}{c}\text { Lysozyme } \\
(\mu \mathrm{g})(0 \mathrm{hr})\end{array}$ & $\begin{array}{c}\text { Lysozyme } \\
(\mu \mathrm{g}) 04 \mathrm{hr}\end{array}$ & $\begin{array}{c}\text { Lysozyme } \\
(\mu \mathrm{g}) 08 \mathrm{hr}\end{array}$ & $\begin{array}{c}\text { Lysozyme } \\
(\mu \mathrm{g}) 24 \mathrm{hr}\end{array}$ \\
\hline 1. Control & $740 \pm 08$ & $700 \pm 20$ & $551 \pm 193$ & $345 \pm 03$ \\
\hline $2.10^{3}$ dose & $693 \pm 28.9$ & $613 \pm 95.2$ & $1070 \pm 199$ & $1290 \pm 38$ \\
\hline $3.10^{5}$ dose & $732 \pm 10.7$ & $1043 \pm 484$ & $856 \pm 211$ & $959 \pm 197$ \\
\hline $4.10^{9}$ dose & $737 \pm 41.7$ & $842 \pm 221$ & $689 \pm 68.2$ & $572 \pm 88.9$ \\
\hline
\end{tabular}

Control (PBS only injected), Lysozyme level was measured every 4 hours interval, Value presented as mean $\pm \mathrm{SD}$ 
Table 4 Serum bactericidal activity (KI) of halibut serum collected from the fish that received different doses of Aeromonas salmonicida (MT423) challenged with intraperitoneally

\begin{tabular}{|c|c|c|c|c|}
\hline $\begin{array}{l}\text { Number of } \\
\text { bacterial } \\
\text { challenged }\end{array}$ & $\begin{array}{c}\text { K- } \\
\text { Index(KI)- } \\
\text { Ohr }\end{array}$ & $\begin{array}{c}\text { K-Index(KI)- } \\
04 \mathrm{hr}\end{array}$ & $\begin{array}{l}\text { K.Index } \\
\text { (KI)-08hr }\end{array}$ & $\begin{array}{l}\text { K.Index(KI)- } \\
24 \mathrm{hr}\end{array}$ \\
\hline 1.Control & $0.690 \pm 0.032$ & $1.220 \pm 0.231$ & $0.554 \pm 0.242$ & $0.595 \pm 0.01$ \\
\hline $2.10^{3}$ & $0.517 \pm 0.135$ & $1.359 \pm 0.524$ & $0.620 \pm 0.134$ & $1.130 \pm 0.187$ \\
\hline $3.10^{5}$ & $0.441 \pm 0.096$ & $0.866 \pm 0.117$ & $0.577 \pm 0.042$ & $1.084 \pm 0.090$ ** \\
\hline $4.10^{9}$ & $0.670 \pm 0.101$ & $1.046 \pm 0.103 * *$ & $0.612 \pm 0.093$ & $1.839 \pm 0.330$ ** \\
\hline
\end{tabular}

The serum collected at every 4 hours interval, ** indicates the nonkilling activity of serum, Value presented as mean \pm SD

immune system, the lysozyme activity decreases and the bactericidal activity also decreases. As far as virulent action of A.salmonicda (MT 243) is concerned, two virulent factors such as casinolyitc protease and a haemolysin have so far been identified among the extra cellular products (ECP) from MT423(Ellis,1990). If the level of ECP reached lethal levels, the ECP might neutralise or inactivate the lysozyme and other non-specific proteins in serum.

Ellis (1981) pointed out that serum inactivation of ECP was not due to complement activation but rather to a protease inhibitor present in fish serum. Moyner (1993) noted that the protease activity is present in salmon sera and increased during acute furunculosis as it was observed better bactericidal activity in $10^{5}$ cells/fish was injected even though it showed low lysozyme level. Further, Sakai (1983) pointed out complement mediated bactericidal action against $A$. salmonicida is through the alternative pathway. The gradual increase of lysozyme in serum of fish injected with $10^{3}$ cells and sudden increased of lysozyme in $10^{5}$ cells /fish injected fish are suggested that it could be due to activation of lysozyme by stimulation of macrophages due to opsonization.

As lysozyme is believed to play an antibacterial role during infection, causing lysis of bacterial cell walls and opsonization of macrophages, it acts specifically against gram (+) ve bacteria. The results of the present study found that hen egg white lysozyme did not have any bactericidal effect upon Gram (-)ve bacteria Aeromonas salmonicida . However, Grinde (1989) demonstrated bactericidal activity of rain bow trout lysozyme upon A.salmonicida . As Gram(-)ve bacteria possess LPS membrane around the cytoplasmic membrane. Withholt et al. (1978) stated that lysozyme penetrates the outer membrane in Gram (-)ve bacterium under mild osmotic shock. The outer membrane of gram (-)ve bacteria external to and covalently linked to the peptidoglycan and serves as a permeability barrier. Because of this diffusion barrier, lysozyme would not be able to gain access to the peptigycan. However, the degree of susceptibility under an optimum situation has generally been used as an index of the lysozyme potential as an antibacterial agent (Studnicka et al. 1986). In the present study, turbidometric method was applied to measure the lysozyme level in units and it was found to be the most accurate and convenient method among other methods used. It was found that when the bacteria is lysed by lysozyme activity, the turbid nature of the reaction mixture decreases and, therefore the absorbance decreases. The decrease in optical density gives a measurement of the lysozyme activity (OD/min). Of the fish serum examined, Atlantic salmon shows significantly low level of lysozyme activity in comparison with the lysozyme activity of halibut serum $(\mathrm{P}<0.001)$ and the lysozyme activity of individual fish from within a single species varied considerably. Lie et al. (1986) pointed out the differences in lysozyme activity between individuals is probably attributable to the different enzyme concentration rather than to the specific activities of different types of enzymes. It appears that lysozyme activity of halibut serum is lower in winter than in summer. Along with other nonspecific humoral proteins, the lysozyme levels respond to physical and environmental changes (Ellis,1981). The higher levels of lysozyme activity in halibut in the summer could be due to exposure to high temperatures, which may have reached the upper thermal limit of halibut. With regard to the bactericidal activity of serum against A.salmoinicida (MT423), there was shown to be no significant correlation with the lysozyme level in serum.

In Atlantic salmon and halibut, Atlantic salmon showed very poor bactericidal activity (KI>1) whereas in halibut, four fish of eleven halibut did not show bactericidal activity eventhough it posses high levels of lysozyme activity. It is explained why serum did not show effective killing activity against the bacterium A.salmonicida which is a virulent and sophisticated salmonid pathogen. It has been suggested that A-layer could act as a major virulence factor (Ellis, 1988) and in vitro studies have shown that the surface structure of A.salmonicida provides good protection against complement activity. Both the A-protein and long polysaccharide O-antigen chains of the LPS contribute to this protection, presumably by low levels of the non-specific activation and non-specific humoral proteins or by minimizing access of the various components of complement to their target. One important role for the A-layer in virulence appears to be protection of A.salmonicida from the bactericidal activity of complement (Munn et al., 1992).

The MIT bactericidal assay (Peck, 1985) used during the study to evaluate serum killing potential has several advantages over other methods. There are considerable savings in time and materials and accuracy is proved when compared with conventional colony counting. The tetrazolium dye, MIT (3-4-5-di-methylthioazoyl-25-diphenyltetrazoilum bromide), is reduced by dehydragenases from the bacteria and forms a purple formazan that can be easily 
quantified by measuring optical density. At $0 \mathrm{~h}$, reduction of the MIT is produced by large numbers of living bacteria. This is compared with reduction after $1 \mathrm{~h}$ incubation, by which time any cell death should have occurred. This is very sensitive assay to detect the growth of bacteria, especially in serum killing and macrophage mediated killing experiments. From this trial it could be proposed that lysozyme was not involved in bactericidal activity against A.salmonicida (MT 423) and halibut are most resistance to A.salmonicida infection. Bactericidal activity may be due to acute phase proteins or other humoral proteins in serum of halibut. The humoral proteins are reported to be found in blood and tissue fluid of shrimp species. So, these assays could be used to determine the lysozyme activity in commercial shrimp species and also will be worthwhile study to understand the resistance shrimp species which show resistance to wide range of bacterial infection. In addition, lysozyme is a stress related factor, it will be useful to know the environmental and physical stress effect in the culture shrimp species using the changes of lysozyme level.

\section{Conflict of Interest}

The authors declare that they have no conflict of interests.

\section{References}

Alhazmi A, Stevenson JW, Amartey S, Qin W (2014) Discovery, Modification and Production of T4 Lysozyme for Industrial and Medical Uses. International Journal of Biology 6: doi:10.5539/ijb.v6n4p45

Austin B, Austin DA (1987) Bacterial Fish Pathogens. Ellis Horwood Ltd, London, Pp. 111-195.

Barnes RD (1974) The crustaceans. In: Invertebrate Biology, W.B Saunders Company, London: 511-513.

Bricknell IR, Bron JE, Bowden TJ (2006) Diseases of gadoid fish in cultivation: a review. ICES Journal of Marine Science 63:253266. DOI: https://doi.org/10.1016/j.icesjms.2005.10.009.

Cheng TC Chorney MJ, Yoshino TP (1977) Lysozyme like activity in the hemolymph of Biomphalaria glabrata challenged with bacteria. Journal of Invertebrate Pathology 29: 170-174.

Costello MJ (2009) The global economic cost of sea lice to the salmonid farming industry. Journal of Fish Diseases 32:115-118. DOI: $10.1111 / \mathrm{j} .1365-2761.2008 .01011$.

Ellis AE (1981) Stress and modulation of the immune response in fish. In: Pickering AD (Ed.) Stress and Fish, Academic Press, Londonpp, Pp. 147-167.

Ellis AE (1988) Current aspects of fish vaccination. Diseases of Aquatic Organisms, 4: 159-164.
Ellis, A.E. (1990) Lysozyme Assays. In: Stolen JS, Fletcher TC, Anderson DP, Roberson BS, Van Muiswinkel WB (Eds.), Techniques in Fish Immunology, SOS Publications, Fair Haven, Pp. 101-103.

Fletcher TC, White A (1973) Lysozyme activity in the plaice (Pleuronectes platessa L.). Experientia 29: 1283-1285.

Grinde B (1989) Lysozyme from rainbow trout, Salmo gairdneri Richardson, as a antibacterial agent against fish pathogens. Journal of Fish Diseases 12: 95-104. DOI: 10.1111/j.13652761.1989.tb00281.x.

Ingram GA (1980) Substances involved in the natural resistance of fish to infection-A review. Journal of Fish Biology 16: 23-60. DOI: $10.1111 / \mathrm{j} .1095-8649.1980 . t b 03685 . x$.

Lie O, Syed M, Solbu H (1986) Improved agar plate assays of bovine lysozyme and haemolytic complement activity. Acta Veterinaria Scandinavica 27: 23-32.

Lindsay GJH (1986) The significance of chitinolytic enzymes and lysozyme in rainbow trout Salmo gairdneri defence. Aquaculture 51: $169-173$.

McCarthy DH, Roberts RJ (1980) Furunculosis of fish--the present state of our knowledge. In: Droop MR, Jannasch HW (Eds.), Advances in Aquatic Microbiology, Vol. 2. Academic Press, London. Pp. 293-341

Mock A, Peters G (1990) Lysozyme activity in rainbow trout, Onchorynchus mykiss (Walbaum), stressed by handling, transport and water pollution. Journal of Fish Biology 37: 873-885. DOI: 10.1111/j.1095-8649.1990.tb03591.x.

Moyner K (1993) Changes in serum protein composition occur in Atlantic salmon, Salmo salar L., during Aeromonas salmonicida infection. Journal of Fish Diseases 16: 601-604. DOI: 10.1111/j.1365-2761.1993.tb00897.

Munn CB, Ishiguro EE, Kay WW, Trust TI (1982) Role of surface components in serum resistance of virulent Aeromonas salmonicida. Infection and Immunity 36 : 1069-1075.

Murray CK, Fletcher TC (1976) The immunological localization of lysozyme in plaice (Pleuronectes platessa L.) tissues. Journal of Fish Biology 9: 329-334. DOI: 10.1111/j.10958649.1976.tb04681.x.

Ossermann EF, Lawlor DP (1966) Serum and Urinary lysozyme (Muramidase) in monocytic monomyelocytic leukaemia. Journal of Experimental Medicine 124:921-951. 
Ourth DD, Wilson EA (1981) Agglutination and bacterial responses of the channel catfish to Salmonella paratyphi. Developmental and Comparative Immunology 5: 261-270. DOI: https://doi.org/10.1016/0145-305X(81)90033-1.

Parry RM, Chandan RC, Shahani KM (1965) A rapid and sensitive assay of muramidase. Proceedings of the Society for Experimental Biology and Medicine 119: 384-386.

Pech R (1985) A one plate assay for macrophage bactericidal activity. Journal of Immunological Methods 82: 131-140.

Rainger GE, Rowley AF (1993) Antibacterial activity in the serum and mucus of rainbow trout, Onchorhynchus mykiss, following immunization with Aeromonas salmonicida. Fish and Shellfish Immunology 3: 475-482. DOI: https://doi.org/10.1006/fsim.1993.1046.

Reddy KVR, Yedery RD, Aranha C (2004) Antimicrobial peptides: premises and promises. International Journal of Antimicrobial Agents 24: 536-547. DOI: https://doi.org/10.1016/j.ijantimicag.2004.09.005.

Sakai DK (1983) Lytic and bacterial properties of salmonid sera. Journal of Fish Biology 23: 457-4566. DOI: 10.1111/j.10958649.1983.tb02926.x.
Sharp GJE, Secombes CJ (1993) The role of reactive oxygen species (ROS) in the killing of the bacterial fish pathogen Aeromonas salmonicida by rainbow trout macrophages. Fish \& Shellfish Immunology 3: 119-129.

Studnicka M, Siwicki A, Ryka B (1986) Lysozyme level in carp (Cyprinus carpio L). Bamidgeh 1: 22 -25.

Ugelvik MS, Skorping A, Moberg O, Mennerat A (2017) Evolution of virulence under intensive farming: Salmon lice increase skin lesions and reduce host growth in salmon farms. Journal of Evolutionary Biology 30: 11361142. doi:10.1111/jeb.13082.

Wang S, Ng TB, Chen T, Lin D, Wu J, Rao P, Ye X (2005) First report of a novel plant lysozyme with both antifungal and antibacterial activities. Biochemical and Biophysical Research Communications 327: 820-827. DOI: https://doi.org/10.1016/j.bbrc.2004.12.077.

Withholt B, Boekhout M (1978) The effect of osmotic shock on the accessibility of the murein layer of exponentially growing Escherichia coli to lysozyme. Biochimica et Biophysica Acta (BBA) - Biomembranes 508: 296-305. 